\title{
MyLinkFace: Teaching SOCIAL ENTREPRENEURSHIP
}

\author{
Lynn A. Fish and fi-Hee Kim
}

Lynn A. Fish is Professor of Management and Ji-Hee Kim is Associate Professor of Management, Richard J. Wehle School of Business, Canisius College

\begin{abstract}
Teaching students' ethically and socially responsible decision-making can be a daunting task for any instructor. This paper outlines a social entrepreneurship course that is built upon evolving best teaching practices in the area - reflection, mentoring and active learning, and demonstration of learning that occurs can be noted through a very successful outcome of course, a new venture. MyLinkFace, where students reach across international borders to deliver language services, demonstrates all aspects of social entrepreneurship including social innovation, financial sustainability, scalability, and social impact being balanced with entrepreneurial education themes of opportunity recognition, business models, growth strategies, and financial performance. Through the new venture, entrepreneurship students develop social entrepreneurial skills, education majors
\end{abstract}




\section{The BRC Academy Journal of Education Vol. 4, No. 1}

improve their teaching skills, and beneficiaries develop their conversational English language. Essentially, everyone wins!

Keywords: Social Entrepreneurship, entrepreneurship education

DOI: http://dx.doi.org/10.15239/j.brcacadje.2014.04.01.ja02

\section{LiterATURe Review}

While business entrepreneurship changes the face of business, social entrepreneurship challenges people to positively change society. While there is no specific academic or practitioner definition, social entrepreneurship is the recognition of a social problem and the use of entrepreneurial principles in creating, organizing, and managing a social venture to achieve a desired social change ("The Social Entrepreneur Bill Drayton", 2005). (When practiced in the global arena, it is called international social entrepreneurship.) Social entrepreneurship education programs exist in universities worldwide and must meet the educational needs of social entrepreneurs seeking business skills, an increased attention to social issues, and students' desires for meaningful educations (Miller, Wesley, \& Williams, 2012). Social entrepreneurship is attracting a growing interest in how to teach people the necessary social and entrepreneurial skills (Howorth, Smith, \& Parkinson, 2012). However, consensus about the necessary competencies for these programs does not exist (Miller et al., 2012).

Social entrepreneurship requires a skill set beyond those needed to manage a traditional profit-centered organization - beyond assessment of an organizations social mission or entrepreneurial skill to managing social and economic conflict (Smith, Besharov, Wessels, \& Chertok, 2012). Experts acknowledge that social and commercial entrepreneurs face similar pressures from resource constraints, environmental uncertainty, and an uncertain marketplace (Howorth et al., 2012). Social enterprise sustainability requires entrepreneurial and managerial skills in such areas as: assessment of funding streams, profitability analysis for 
reinvestment, resource management, idea generation and exploitation, and market distribution and assessment analysis. Several educational models recently emerged to address the necessary skill set for social entrepreneurship. The objective here is not to review all of these models, but to highlight this emerging skill set and then demonstrate how these developed in a social entrepreneurship class.

To begin, social entrepreneurs must acquire leadership skills in accepting, differentiating and integrating competing demands (Smith et al., 2012). Social entrepreneurship involves accepting and creating a vision that accepts both social and financial demands simultaneously - and not as conflicting viewpoints. Differentiating requires recognition of unique contributions from both the financial and social areas and recognizing the unique distinctions between them. Social entrepreneurs must balance the social mission with the commercial mission in creation of a viable business strategy. Instructors need to create divergent thinking exercises that foster skills to attend to novel distinctions (Smith et al., 2012). Simultaneously, social entrepreneurs need to develop integration skills that focus on creating 'win-win' situations between the social and financial arenas. Integration requires identifying creative synergies between contradictory elements with the goal of a productive outcome (Smith et al., 2012). Developing integrative options requires complex thinking based upon developing decision-making skills towards synergistic solutions and interpersonal skills that focus on building trust, openness and cultural sensitivity (Smith et al., 2012). Instructors can use transformational groups and exercises to foster interpersonal skills and create an environment and understanding that develops skills to recognize and manage conflicting views. Experts argue that developing these skills depends upon curricula that allow students to learn from others, create community, and manage conflict through adapting course structures and processes to facilitate this learning and not merely adding new content to existing courses (Smith et al, 2012). 


\section{The BRC Academy Journal of Education Vol. 4, No. 1}

From an educational perspective, pedagogical themes include social innovation, financial sustainability, scalability, and social impact being balanced with entrepreneurial education themes of opportunity recognition, business models, growth strategies, and financial performance, respectively (Kickul, Janssen-Selvadurai, \& Griffiths, 2012). Goals in teaching social entrepreneurship include teaching students to identify innovative solutions to social problems, developing a business model for sustainability, inspiring others to embrace a vision and values, identifying multiple and varied sources of funding, identifying means of scaling, timely implementation for social solution and measurement of the social impact of the endeavor (Kickul et al., 2012). Instructors - and their students - must learn to take advantage of the intrauniversity resources and the social community resources toward accomplishing their goals. In today's environment, public-private collaboration is playing an increasingly more important role in new venture creation and requires an in depth learning of collaborative habits, knowledge and skills (Kickul et al., 2012).

With respect to scaling, students need to consider four dimensions - impact, need, organization and timing - that outline the potential benefits, risks and costs of the potential venture (Bloom \& Chatterji, 2009). Scaling a program may be viewed as a 4-step process for deciding whether and how to scale by defining the social enterprise, its scaling and replicability, opportunity assessment, evaluation of the social enterprise's readiness and formulation of a scaling-up strategy (Taylor, Dees \& Emerson, 2002).

Experts in teaching social entrepreneurship advise that the course should include a preparation exercise followed by an experiential experience (Kickul et al., 2012). Similarly, social entrepreneurship may be accomplished best through a collaborative experience with other professional disciplines and fields following the best practices taught through social entrepreneurship (Kickul et al., 2012). Student learning assessment needs to be formative, summative, and reflective in nature. 
Other experts preach that teaching social entrepreneurs should be social and not contextual learning, and in particular, skills in reflective thinking may be particularly beneficial to social entrepreneurs (Howorth et al., 2012). Reflective thinking requires critical questioning about assumptions and mental models that in the past may have been taken for granted. Experts argue that building trust, familiarity and psychological safety are important in developing social entrepreneurial skills (Howorth et al., 2012). In one study, social and commercial entrepreneurs appear to have more in common than differences (Howorth et al., 2012). Both students benefit from reflective thinking, mentoring and action learning sets along with practice through mutual engagement with others in peer-to-peer learning, joint enterprise and information sharing. Educators need to create environments that foster the commonality and learning from both commercial and social entrepreneurial environments with a particular emphasis on practice and social learning versus contextual learning.

Recent research highlights competencies that social entrepreneurship educational environments appear to include learning to (Miller et al., 2012):

- Qualitatively and quantitatively measure social outcomes, including understanding social return on investment, blended value accounting, social-costs accounting and other social measures;

- Develop sustainable, empowered problem-solving to address society situations that are engrained in communities, governments and infrastructures by developing process solutions that go beyond mere solutions;

- Manage financial capital and social finance that delivers an economic return and social dividend;

- Identify, evaluate and exploit opportunities;

- Create, evaluate the feasibility and implement a strategic business plan;

- Be innovative and creative; 
- Formulate a strategy that addresses value chains and business models that serve the intended beneficiaries and generate financial returns for the organization;

- Develop inter-personal abilities towards collaborative relationships by networking and stakeholder management; and

- Communicate with all stakeholders including customers, suppliers, beneficiaries and employees.

However, experts highlight the need for more attention in the social entrepreneurship classroom on developing marketing and selling; a sense of moral imperatives and ethics; critical thinking to challenge traditional ways; leadership and team development; and social and interpersonal skills (Miller et al., 2012). Recent research also highlights differences in social entrepreneurship education between the graduate and undergraduate levels where graduate education appears to focus on managing financial capital, measuring outcomes, and growing the organization, while undergraduate programs tend to focus on social problem identification (Miller et al., 2012).

With these competencies and skills in mind, the social entrepreneurship course, ENT314, and the social entrepreneurial venture, MyLinkFace, which resulted from the curriculum are described.

\section{METHOD: ENT314: Social ENTREPRENEURSHIP}

The junior-level, undergraduate elective is open to all students who complete the pre-requisites; however, the course is mainly populated by entrepreneurship and business students. Pre-requisites to ENT314 Social Entrepreneurship include MGT101 Introduction to Management and MKT 201 Principles of Marketing (Entrepreneurship Section) or ENT 201 Introduction to Entrepreneurship and junior standing. In the spring of 2010, ENT314, a junior-level elective for the entrepreneurship major included 21 students. (Subsequently, 19 and 29 students took the course in the spring of 2011 and 2012 respectively.) The practitioner-oriented 
course focuses on innovative, value-driven organizations that have civic or social missions and are typically associated with the not-for-profit sector. The course goals are to teach students the role of the not-forprofit sector in creating social wealth in the economy, to actively engage students in institutional efforts to create a positive social impact, and to engage students through mentorships with aspiring entrepreneurs while preparing them for leadership roles in their communities. The specific educational objectives are:

1. To examine the distinctive challenges and rewards of entrepreneurship and management in creating and developing social purpose organizations.

2. To develop the knowledge, skills, and attitudes necessary for responding creatively and effectively to the challenges.

3. To provide an appreciation of the relative strengths and weaknesses of different organizational forms in providing social goods and services.

The course focus is on developing entrepreneurial and business skills toward the creation and management of social enterprises. Through the course, students develop a conceptual framework and techniques for thinking strategically about innovation in the social sector. The course uses the textbook, Social Entrepreneurship: A Modern Approach to Social Value Creation by A. C. Brooks (2009). The course concentrates on the seven modules (as outlined below) and the development of a written business plan for a not-for-profit organization through a student team. (Interested readers may request a syllabus from Dr. JiHee Kim.)

The seven modules, which assist students in developing the non-profit business plan and interwoven into the chapters, are as follows:

- Module I. Undertaking the Social Entrepreneurship Process focuses on critical issues an entrepreneur faces in creating and sustaining a social purpose organization.

- Module II. Mobilizing Economic and Human Resources. Acquiring capital and talent for a social enterprise, a key function of the 
social entrepreneur, is the focus of this module. Particular emphasis is given to innovative sources of financing, such as venture philanthropy and the Internet.

- Module III. Achieving Social Objectives with Commercial Ventures examines a number of creative approaches and organizational structures used by for profit and nonprofit companies to address social issues. The market place is used as the primary vehicle for generating the resources needed for social betterment.

- Module IV. Crafting Alliances is becoming an increasingly integral part of social enterprise strategy. This module examines the opportunities and risks associated with building alliances between and among nonprofit, business, and government organizations.

- Module V. Managing Growth explores the distinctive challenges associated with the growing of social enterprises. For social entrepreneurs who successfully make it through the start-up stage, the next major challenge is getting bigger.

- Module VI. Measuring and Managing Performance deals with perhaps the most complicated and distinguishing managerial feature of social enterprises compared to commercial businesses.

- Module VII. Governing the Social Enterprise. This two-case module will provide an opportunity to explore the challenges of governance as a critical determinant of effectiveness.

A few points to note regarding the course and best teaching practices:

1) The course begins with each student giving a 1-minute vision, value and self-reflection as a social entrepreneur. Thus, each student starts the course through self-reflection, and by presenting it, starts to build familiarity and peer-to-peer learning.

2) The schedule includes individual and group presentations. These presentations build oral communication skills.

3) Brainstorming a new business idea and financial funding are based upon a required entrepreneurship knowledge and process developed at the freshman level - "From Nothing to Something" (Kim $\&$ Fish, 2010), which is used in the ENT314 course. 
4) The current schedule includes a discussion for scaling of the original venture, MyLinkFace, and group development of a new venture. Through the current course, students address the scalability issue as the students continue to keep MyLinkFace as a viable business while also developing initiation and concept development skills.

5) Students develop a strategic business plan through their group work. Writing and presenting a strategic business plan is a skill that is required throughout each of the entrepreneurship major courses, but specific to this course, focuses on balancing the social and commercial aspects to a business. In particular, the fact that the final strategic plan is reviewed by both the instructor and an outside social entrepreneur provides additional mentoring for the student.

6) The course concludes with individual and group presentations that include a self-reflection component. Each student reflects on their learning through the course, and through their final presentation, each student creatively presents their social entrepreneurship learning.

The course is a blend of lectures, discussions and guest speakers. Throughout the course, the selected cases highlight the diverse economic, political, and cultural characteristics of social sector organizations. To ensure relevancy and a practitioner orientation, the sessions use case studies of social enterprises. These for profit and not-for-profit entrepreneurs lead various types of social enterprises involved in a wide range of social sector causes, encompassing education, health care, economic development, youth services, social advocacy, and environment.

Student evaluation consists of class attendance and participation (14\%), an individual reading and presentation (3\%), case and reading assignments (9 total; 26\%); a not-for-profit group project (43\%) and a final self-reflection presentation and evaluation (14\%). By attending each class and participating in the active dialog that encourages ethical and social responsibility, students' acquire critical thinking, commit- 
ment, and leadership skills. The individual readings and final self-reflection included several social entrepreneurship topics including: what is social entrepreneurship, myths about social entrepreneurship, the creative process of social entrepreneurship, developing the social enterprise concept, social enterprise business planning, measuring social value, earned income, donations and government income, fundraising and marketing, and social entrepreneurship growth strategies. Students must participate in the group activities outside of class as well and are forewarned that these take extensive time and energy. Outside activities include researching non-profit and social sector's organizations typically completed through the Internet, developing the group's business plan, and raising seed money. Student's participation is critical to active learning and contributes to the entire class learning. Active participation also puts the learner in an active mode, thus enhancing learning. The cases and reading assignments test analytical thinking and reflective knowledge of social entrepreneurship. As noted in the tentative schedule, students are expected to submit a chapter summary for each chapter, case summaries, and progress summaries of the business plan. The individual chapter presentation develops each student's oral communication and creativity skills as each student presents a 20-minute presentation on the assigned chapter. The 'brainstormed' class developed, not-for-profit business project develops student's written communication, analytical thinking, and creative problem-solving skills while requiring them to develop innovative marketing strategies, integration, and an entrepreneurial attitude and mindset. The outcome from the project is a new business venture plan that requires viable research. The group is expected to not only write about the project - but to develop it! The business plan is graded by the instructor and an outside social entrepreneur. The course culminates in group project presentations and a final self-reflection presentation. The final exam covers the academic learning from each of the chapters. Each student submits a reflection about the business planning process, raising seed money and forming the social entrepreneurship venture, in this case, MyLinkFace. Thus, the 
course offers a participative pedagogy that is heavily influence by situated learning that encourages entrepreneurial 'thinking outside of the box' and a balance between social and commercial goals.

\section{Assurance of Learning: MyLinkFace}

While assurance of learning can take many forms, the development and continued sustainability of the new venture, MyLinkFace, is a clear demonstration of students' learning social entrepreneurship through active participation. MyLinkFace is the brainchild of students in the 2010 ENT314 Social Entrepreneurship class. It is a student-initiated, studentrun, international, non-profit, social venture that links student teachers in Buffalo, New York to students around the world with the goal of teaching foreign-speaking students conversational English. MyLinkFace delivers conversational English to students through the use of Skype, and requires only a computer, web camera, and an Internet connection. Through the ENT314 course, the students recognized that in the international world, English is the primary language used to conduct business, government, and education. They also noted that fluency is particularly important in countries like South Korea where international business is the backbone of the economy. ENT314 students through their research found that in South Korea, Samsung, Hyundai, and Kia Motors, along with telecommunications conglomerates and the Korean government, are the driving force to enhance the English language skills of the Korean people. Thus, students recognized the need to educate professionals in conversational English.

Social entrepreneurship is particularly effective when other groups are represented. Such is the case with MyLinkFace where business, education and customers come together using Skype. The three key groups involved in MyLinkFace are a management team, student teachers and foreign students. The management team is comprised of students that represent all business functions: accounting, finance, 


\section{The BRC Academy Journal of Education Vol. 4, No. 1}

human resource, operations, marketing and web design. The management team developed and implemented a business plan. The team continues strategic planning while acquiring practical experience in running a business. For example, operations schedules student teachers or web design develops the virtual interface. Students also engage in writing business contracts, maintaining the social network for marketing purposes, advertising, and writing job descriptions. Student teachers, which mainly consist of education or English majors, are the backbone of the operations system as student teachers must develop lesson plans and deliver them to students throughout the world. Foreign students, whether they are undergraduates, graduates or business professionals, enter MyLinkFace with an understanding of the English grammar, sentence structure and vocabulary; however, they lack the ability to converse fluently and understand American idioms. In developing the concept, students researched English as a Second Language (ESL) and used various ESL textbooks currently available on the marketplace.

Current courses offered through MyLinkFace include one-on-one conversational English lessons for business communications, English for airline staff, English for hotel management and English for job interviews and employment. Students learn the proper way to introduce themselves, suitable responses for customer service complaints, appropriate telephone etiquette, and how to prepare for and conduct meetings (Browka, 2011). Each course includes a corresponding textbook, produced by the student teacher.

Start-up issues include obtaining financial backing, marketing, and time differences. Business starts-ups always require capital investment. The students overcame this issue through fund-raisers and sponsorships. Both the management team and student teachers receive minimum wage for their efforts. Breaking into a new untested market with an untested product is always a daunting and challenging task. Starting MyLinkFace proved to be no different. Initially the students conceptualized reaching out to elementary students; however, they were unable to break into this 
market and modified the marketing strategy toward professionals and universities. After a multitude of rejections, Pukyong National University was the first international client.

Students engaged in various fundraising efforts to initialize and sustain the MyLinkFace effort. Initial seed money came from selling a few products on campus (e.g. raffles and flowers), a raffle at a local NHL hockey game, and fundraising at a local NFL event. Once the business started, through various student efforts, a Korean sponsor (ICanSpeak, Ltd.) came forward with both students and financial support.

The social impact measures include the number of customers served, the number of employees and hours worked as members of MyLinkFace, and the number of MyLinkFace employees that become ESL teachers in other countries. In the spring of 2010, 38 customers participated in the pilot program. As shown in Table 1, the 'semester' ranges from 2 to 3 months depending upon the situation, and teachers administer to an average of 70 students that ranges from 64 to 94 clients per semester. Customers include undergraduate and graduates students from several top Korean educational institutions and professionals. 24 students participate in either the management or teaching team over the typical 12week semester, for a total of 1728 hours each semester. The management team consists of 13 members (Chief Operations Officer, human resources, marketing, operations, finance/fundraising, accounting and sales) that invest 6 hours a week for 12 weeks, for a total of 936 hours per semester. The teaching team consists of 11 employees that average 4 hours per week with direct contact with the customers over the 12 weeks, or a total of 528 hours over the semester. The teaching team also invests 2 hours per week in preparation and research \& development, adding another 264 hours per semester. Since 2010, 3 former MyLinkFace teachers went on to become ESL teachers in other countries (Korea, France and Columbia). Through pre- and post- tests, Korean student's English capabilities are tested. As MyLinkFace efforts expanded to local refugees in the Buffalo area, the number of refugees in the local area 
became part of the social measurement system. Currently, the number of refugees provided for through MyLinkFace averages 30 per semester.

Currently, MyLinkFace is sustained through the ENT314 course. MyLinkFace's current strategy for sustainability and scalability is to continue their social venture through provide sponsorships for students and financial support, as well as a home-grown focus on refugees in the Buffalo area.

Additional assurance of learning evidence exists in the annual evaluations and assessment of the course. The summative assessment at the end of the semester is based upon all relevant work noted in the student's final course grade. As noted in Table 2, since the spring of 2009, over $85 \%$ of the students have exceeded the course learning goal.

\section{Discussion}

The ENT314 Social Entrepreneurship curriculum incorporates several evolving best practices to develop a student's social entrepreneurial mindset and processes. Students learn more than just new content through the course; they learn the processes to develop new social enterprises. For example, through the group projects, students learn from others, create community and manage conflict through the processes (Smith et al., 2012). By using a previous learned process ("From Nothing to Something"(Kim \& Fish, 2010)), entrepreneurship students build upon previously acquired skills toward a social need. Through brainstorming activities in the class, students identify innovative solutions to social problems, develop a sustainable business model, vision and mission, identify funding sources and scaling opportunities, implement the social solution and measure the social impact, which are all important skills for the social entrepreneur (Kickul et al., 2012). The processes developed in the course encourage synergistic solutions and through the various presentations and initiation activities, build interpersonal skills 
that encourage trust building, openness and cultural sensitivity, all key practices in social entrepreneurship (Smith et al., 2012).

As experts note (Kickul et al., 2012), student assessment should be formative, summative and reflective in nature as the ENT314 course is. Of particular note, reflective thinking may be particularly beneficial to social entrepreneurs (Howorth et al., 2012). Best practices in learning social entrepreneurship include reflective exercises, mentoring from outside speakers, and active learning through mutual engagement with others in peer-to-peer learning, joint enterprise and information sharing (Howorth et al., 2012), and are all included in ENT314.

Social entrepreneurship academic experts advise that an experiential experience is critical to student learning (Kickul et al., 2012). MyLinkFace is a clear demonstration of experiential learning. Social entrepreneurship requires students to develop qualitative and quantitative measurement of social outcomes, developing sustainable, empowered problem-solving processes, manage financial capital and social finance that returns an economic return and a social dividend, develop processes to identify, explore and exploit opportunities, innovative and creative processes, and strategy formulation all leading toward a viable strategic business plan (Miller et al., 2012). One of the final course activities is to present the business plan which is graded by both the instructor and an outside social entrepreneur. Similarly, experts highlight the need for more attention in the social entrepreneurship classroom on developing marketing and selling; a sense of moral imperatives and ethics; critical thinking to challenge traditional ways; leadership and team development; and social and interpersonal skills (Miller et al., 2012). Obviously, the MyLinkFace venture demonstrates all of these outcomes.

Particularly important to any entrepreneurial venture is the continuation of the entity beyond its initiation and scalability of the business plan. Current ENT314 students wrestle with the issues surrounding continued viability of the MyLinkFace organization - the impact, need, organization and timing along with benefits, risks and costs (Bloom \& 
Chatterji, 2001). Through the course, the MyLinkFace strategy transitioned from initial concept delivery to elementary students to a focus toward collegiate students and professionals to a current strategy toward local outreach activities. Through the sustainability exercises built into ENT314, students develop processes to balance the scalability and replication, opportunity assessment, enterprises' readiness and scale-up strategy, which are key issues that social entrepreneurs must deal with (Taylor et al., 2002).

As demonstrated by the MyLinkFace venture, students learn integration skills that focus on creating 'win-win' situations between the social and financial arenas (Smith et al., 2012) and may best be accomplished through collaboration with other professional disciplines (Kickul et al, 2012). The students in 2010 ENT314 identified a potential solution to a need to develop conversational English and through collaboration with education and English students along with technical capabilities, developed a viable method to assist students throughout the world.

\section{Conclusion}

Teaching social entrepreneurship is an evolving field where best practices are beginning to emerge. The ENT314 course distinctly demonstrates these best practices and student learning of social entrepreneurship. Students build upon previously acquired entrepreneurship and business knowledge to develop their social entrepreneurial skills through the course processes required for identification, collaboration, integration, and reflection. Best practices of mentoring, active learning, and mutual engagement with others (Howorth et al., 2012) are also included in ENT314. The new venture, MyLinkFace, which is now in its third year of existence, demonstrates the viability of the classroom methods to develop a new concept through scaling. 


\section{REFERENCES}

Bloom, P.N. \& Chatterji, A.K. (2009). Scaling social entrepreneurial impact. California Management Review, 51: 114-133. http://dx.doi. org $/ 10.2307 / 41166496$

Brooks, A.C. (2009). Social Entrepreneurship: A Modern Approach to Social Value Creation. Pearson Prentice Hall, 1st Ed. Pearson Education Inc. Upper Saddle River, New Jersey.

Browka, A. (2011). Virtual classroom real experience: A new studentinitiated, student-run social venture takes distance learning to the extreme. Canisius College Magazine, Spring 2011, pp. 6-9.

Howorth, C., Smith, S.M. \& Parkinson, C. (2012). Social Learning and Social Entrepreneurship Education. Academy of Management Learning \& Education, 11(3), pp. 371-38. Retrieved on 1/3/2013 from http://dx.doi.org/10.5465/amle.2011.0022

Kickul, J., Janssen-Selvadurai, C. and Griffiths, M. (2012). A blended value framework for educating the next cadre of social entrepreneurs. Academy of Management Learning \& Education, 11 (3), pp. 479-493. Retrieved on 1/3/2013 from http://dx.doi.org/10.5465/amle.20U.0018

Kim, J. and Fish, L.A. (2010). From Nothing to Something: An Experiential Entrepreneurship Experience. Decision Sciences Journal of Innovative Education: Teaching Papers, January 2010, 8(1), pp. 241-255. http://dx.doi.org/10.1111/j.1540-4609.2009.00253.x

Miller, T.L., Wesley II, C.L. \& Williams, D.E. (2012). Educating the Minds of Caring Hearts: Comparing the Views of Practitioners and Educators on the Importance of Social Entrepreneurship Competencies. Academy of Management Learning \& Education, 11(3), pp. 349-370. Retrieved on 1/3/2013 from http://dx.doi.org/10.5465/amle.2011.0017

Smith, W.K., Besharov, M.L., Wessels, A.K. and Chertok, M. (2012). Model for Social Entrepreneurs: Challenges, Leadership Skills, and Pedagogical Tools for Managing Social and Commercial Demands. Academy of Management Learning \& Education, 11(3), 463-478. Retrieved on 1/3/2013 from http://dx.doi.org/10.5465/amle.2011.0021 
40 The BRC Academy Journal of Education Vol. 4, No. 1

Taylor, M. Dees, G. \& Emerson, J. (2002). The question of scale: Finding an appropriate strategy for building on your success. In G. Dees, J. Emerson, \& P. Economy, (Eds.), Strategic tools for social entrepreneurs: Enhancing the performance of your enterprising nonprofit. Wiley.

"The Social Entrepreneur Bill Drayton". US News \& World Report. 2005-10-31. Retrieved on 1/3/2013 from http://www.usnews.com/ usnews/news/articles/051031/31drayton.htm.

\section{Web APpendix}

A web appendix for this paper is available at:

http://dx.doi.org/10.15239/j.brcacadje.2014.04.01.wa02

\section{Citation Information}

Fish, Lynn A. and Ji-Hee Kim. "MyLinkFace: Teaching Social Entrepreneurship." The BRC Academy fournal of Business 4, no. 1 (2014): 23-40. http://dx.doi.org/10.15239/j.brcacadje.2014.04.01.ja02 